\title{
Comparison Study on Soil Physical and Chemical Properties, Plant Growth, Yield, and Nutrient Uptakes in Bulb Onion from Organic and Conventional Systems
}

\author{
Jongtae Lee ${ }^{1}$, Sunkyoung Hwang, Seongtae Lee, Injong Ha, \\ Haejun Hwang, Sangdae Lee, and Juyeon Kim \\ Gyeongnam Agricultural Research and Extension Services, Onion Research \\ Institute, Hyojeongri 591, Daejimyeon, Changnyeong 635-821, Republic of \\ Korea
}

Additional index words. organic agriculture, fertilization, soil fertility, nutrient uptake, intermediate-day onion

\begin{abstract}
This study aimed to compare agricultural practices, soil physical and chemical properties, growth characteristics, and nutrient uptake of bulb onions from organic and conventional farms in southeastern Korea during the 2011-12 growing season. Soil and plant samples were collected from eight certified organic fields managed organically for more than 5 years and eight conventional fields adjacent to the organic fields. The amounts of nutrients applied to onion fields were approximately two times greater with the conventional methods than with organic methods. However, the soil physical and chemical properties were not significantly different between the organic and conventional systems, except for $\mathrm{NO}_{3}-\mathrm{N}$ in early May. Growth characteristics were significantly different in early April with organic bulb yield of $55.9 \mathrm{t} \cdot \mathrm{ha}^{-1}$, which was $\mathbf{2 1 . 8 \%}$ lower than conventionally produced onions. Yield reduction in organic onions was the result of lower large-sized ( $8 \mathrm{~cm}$ or greater) bulb yield compared with conventional production. In the conventional system, phosphorus (P) and potassium (K) content of leaf tissue in early April, and nitrogen $(N)$ and $P$ content of bulb tissue in early May were higher than those in the organic system. Uptake of all nutrients was greater in the conventional onions compared with the organic onions, except for leaf tissue at harvest. In conclusion, organic onions began to grow and absorb soil nutrients later than the conventional onions in the initial vegetative growth stage. Moreover, it led to an organic onion producing a lower bulb yield. To accelerate the initial growth of the organic onion plant, agricultural practices need to be modified. Modifications that may help include using larger sized seedlings at transplanting, covering the plants with nonwoven fabric or transparent plastic film to increase warmth during winter, and harvesting the onions 1 week later than the conventional onions.
\end{abstract}

Onion (Allium cepa L.) is one of the most important vegetable crops grown in Korea. Bulb onion growers reported a total area of 20,036 ha, producing 1.29 million tons of onions [Statistics Korea (KOSTST), 2013]. The vast majority of this area is managed using conventional production practices. Organically certified onions are produced from 122 ha, which was only $0.58 \%$ of total

Received for publication 30 July 2014. Accepted for publication 2 Oct. 2014

We thank George Boyhan for writing assistance and suggestions to improve this manuscript. The research was carried out with the support of "Cooperative Research Program for Agriculture Science \& Technology Development (Project title: Enhancement of bulb quality and productivity in organic onion production, Project No. PJ008727)" from the Korean Rural Development Administration, Republic of Korea.

${ }^{1}$ To whom reprint requests should be addressed; e-mail organicjt@hotmail.com. onion production [National Agricultural Products Quality Management Service (NAQS), 2013]. In Korea, the certification for environment-friendly agricultural products has two separate systems: organic and pesticide-free. Organic products cannot use synthetic agrochemicals and chemical fertilizers, whereas pesticide-free production allows chemical fertilizers below one-third of the recommendation rate. These systems have been supported by the Environment-friendly Agriculture Fosterage Act since 1997 (NAQS, 2013). The onion production area from both certification systems was 127 ha in 2005, 493 ha in 2008, and reached 1464 ha in 2011. However, it rapidly decreased thereafter with 886 ha in 2013 (NAQS, 2013). These changes were generated mainly by the pesticide-free certification. The organic certified area ranged from 82 ha to 165 ha since 2008. Reduction in pesticide-free onion production and stagnation in organically produced onions are the result of several reasons. First of all, because the price of conventional onions was high in recent years, the price premium of certified onions was not as attractive to growers. Second, certified onion growers persistently have been bearing a burden of higher management costs and lower productivity (Sellen et al., 1995). According to organic growers, a low yield of certified onions is the result of poor seedlings with poor establishment followed by an increase in frost injury during winter, restrictions on the use of organic manure compost, and dependence on organic fertilizers such as oil cakes. Pest and weed pressure have also played a role. Lastly, the shortage of marketing strategies resulted in growers not receiving adequate returns.

Certified onion growers generally believe that organic bulb yield is lower compared with conventional production because organic onions are not allowed to receive any chemical fertilizer or uncertified manure compost. Hence, they try to apply as much compost or organic fertilizer as possible. However, many researchers have reported that the fertilization system is not the main problem for achieving an optimum bulb yield (Lee, 2010; Mogren et al., 2009; Mousa and Mohamed, 2009; Saviello et al., 2013; Yoldas et al., 2011). In addition, the excessive compost or organic compliant fertilizer rates often resulted in decreased bulb yield (Abdelrazzag, 2002; Boyhan et al., 2010; Lee, 2012; Vidigal et al., 2010).

Onion nutrient content and bulb mineral uptake were examined to determine the nutritional status for optimum yield (Fink et al., 1999; Zink, 1966). The amount of nutrient uptake by an onion crop is very small from germination to bulb initiation; after this period, there is rapid nutrient uptake with the start of bulb initiation and continues through bulb growth (Sullivan et al., 2001). Nutrient uptake at harvest was not different between the onion plant receiving organic fertilizer or cattle manure vs. chemical fertilizer when other agricultural practices were the same, and the bulb yield from both treatments was not different (Lee, 2010; Yoldas et al., 2011). However, organic onions mulched with plastic film showed significantly higher $\mathrm{N}, \mathrm{P}$, and $\mathrm{K}$ uptake as well as increased saleable yield compared with non-mulched cultivation (Lee, 2010).

Several studies have investigated the production effects of plastic mulch on bulb onion. Varina and Roka (2000) reported that black mulch increased the yield of marketable bulbs compared with bare-ground culture in southern Florida. In Korea, Suh and Kim (1991) reported higher soil water content, soil temperature, and onion yields in transparent or black polyethylene vs. no mulch in fall-transplanted intermediate-day onions. The total yield was highest with transparent plastic film with maximum soil temperature at $10 \mathrm{~cm}$ deep that was $1.0{ }^{\circ} \mathrm{C}$ higher than with black plastic mulch from December to February. Although transparent polyethylene is effective for increasing the soil temperature and bulb yield, chemical herbicide is necessary to control weeds. Hence, organic onion growers 
tend to use black mulch for better weed control. We hypothesized that the yield reduction in organic onions did not result from the fertilization program, but from other agricultural practices such as mulching, weed control, pest management, etc.

The aim of the present study was to compare the agricultural practices, soil physical and chemical properties, growth characteristics, and nutrient uptake of organic vs. conventional farms concerning bulb yield between the two systems.

\section{Materials and Methods}

Field experiment. The present experiment was conducted in Hamyang county (lat. $35^{\circ}$ $\mathrm{N}$, long. $127^{\circ} \mathrm{E}$ ) and Sangju county (lat. $37^{\circ}$ $\mathrm{N}$, long. $128^{\circ} \mathrm{E}$ ), located in southeastern Korea, in the 2011-12 growing season. Experimental sites came from eight organic certified fields and eight conventional fields adjacent to the organic fields. Four organic and four conventional fields were located in Hamyang county and four organic and four conventional fields in Sangju county. The soil type of organic fields consisted of loamy sand (one site), sandy loam (two sites), loam (one site), and silty loam (four sites), whereas the soil types of conventional fields consisted of loamy sand (one site), sandy loam (three sites), loam (two sites), and silty loam (two sites). Certified fields were managed organically for more than 5 years. Onion seed, cv. Powerball (an $F_{1}$ hybrid, intermediate-day cultivar for fall transplanting), was grown in all of the experimental fields. Other cultural practices were performed according to participatory farmers? usual practices. For more details on crop management in the trials, see Table 1.

Plant and soil sampling. Plant samples were collected on 4 and 5 Apr. (at the initial vegetative stage), 7 and 8 May (at the initial bulbing stage), and from 5 to 25 June for organic onions and from 8 to 19 June for conventional onions several days before the farmers harvested the onion bulbs. Five plants were pulled from three replications from each field on the dates of sample collection. Onion height, number of leaves, bulb diameter, and fresh weight were measured. Onions were harvested from $\approx 3 \mathrm{~m}^{2}$ in three replications several days before the farmers harvested the onion bulbs. Harvested onion plants were separated into bulbs and tops. The tops were weighed in the field and five top samples were saved for nutrient analysis. All of the harvested onion bulbs (100 to 120) were weighed and their bulb diameters were determined. Bolted, doubled and rotten onions, and onions less than $40 \mathrm{~mm}$ in bulb diameter were culled as unmarketable yield. Marketable bulbs were distributed in the following size classes based on the diameter: small, $40 \mathrm{~mm}$ to less than $60 \mathrm{~mm}$; medium, 60 to less than $80 \mathrm{~mm}$; and large, more than $80 \mathrm{~mm}$. Each sample area yield was converted to total bulb weight per hectare. Soil samples were collected from the surface soil $(0$ to $30 \mathrm{~cm})$ at the same sites and dates as the plant samples and before fertilizer and compost application.

Plant nutrient analysis. All samples were separated into bulb and green leaves followed by the measurement of fresh weight (g/plant) and bulb weight (g/plant). The bulbs and leaves were chopped into pieces $\approx 2 \mathrm{~cm}$ square and dried to a constant weight at $105{ }^{\circ} \mathrm{C}$ for $2 \mathrm{~h}$ and at $60{ }^{\circ} \mathrm{C}$ for $22 \mathrm{~h}$. The dried samples were used to analyze the dry matter and inorganic content.

The dried samples were ground, weighed, and dissolved in concentrated $\mathrm{H}_{2} \mathrm{SO}_{4}$ and concentrated $\mathrm{H}_{2} \mathrm{O}_{2}$. Carbon and $\mathrm{N}$ were measured by an elemental analyzer (vario Max, Elementar, Germany) using the ground samples. Atomic absorption spectrophotometer (novAA 300, Analytikjena, Germany) was used to determine the $\mathrm{K}$, calcium $(\mathrm{Ca})$, and magnesium (Mg) content (Slavin, 1968). Phosphorus was measured colorimetrically with the ammonium-vanadate-molybdate method (Gericke and Kurmies, 1952).

Soil chemical analysis. The bulk density (BD) and water content were measured by a gravimetric method using a $100-\mathrm{mL}$ sampling core. Fresh soil samples were analyzed for $\mathrm{NO}_{3}-\mathrm{N}$, and air-dried soil samples were analyzed for $\mathrm{pH}$, electric conductivity (EC), organic matter $(\mathrm{OM}), \mathrm{N}$, sulfur, available $\mathrm{P}$, and exchangeable cations. Organic matter and $\mathrm{N}$ content were measured by an elemental analyzer (vario Max), and nitrate-nitrogen
$\left(\mathrm{NO}_{3}-\mathrm{N}\right)$ was identified by reflectometry (RQ plus; Merck, US). Soils for analyzing $\mathrm{P}$ and exchangeable cations were extracted using Morgan extractant (McIntosh, 1969). The extracted soil $\mathrm{P}$ was analyzed by a spectrophotometer (Ultraviolet 2450, Shimadzu, Japan), and exchangeable cations were measured by an atomic absorption spectrophotometer. Soil $\mathrm{pH}$ and $\mathrm{EC}$ were determined by a $\mathrm{pH}$ meter and conductivity meter (Thermo Scientific, Orion, MA) using a 5:1 deionized water:soil ratio.

Data analysis. Statistical analyses were performed using XLSTAT Pro 2013.1.01 (Addinsoft, USA). The data were analyzed by one-way analysis of variance and Student's $t$ test to evaluate the significant difference.

\section{Results and Discussion}

Cultural practices. Organic onions were not cropped over 2 years, whereas conventional onions continued to be cropped for more than 7 years in the same fields (Table 1). Planting density was lower in the organic than conventional farms. The average area of organic onions was 0.29 ha, almost half of the conventionally grown area. The compost was applied at a higher rate in conventional fields than in organic fields. The reason for this difference was that conventional farmers can use conventional cattle, swine, or poultry

Table 1. Comparison of agricultural practices of bulb onion production as affected by organic and conventional methods.

\begin{tabular}{|c|c|c|c|}
\hline \multicolumn{2}{|l|}{ Items } & Organic & Conventional \\
\hline \multicolumn{2}{|l|}{ Continuous cropping years } & 1.1 & 7.4 \\
\hline \multicolumn{2}{|l|}{ Sowing time } & Early Sept. & Early-mid. Sept. \\
\hline \multicolumn{2}{|l|}{ Planting time } & Late Oct. & Late Oct. \\
\hline \multicolumn{2}{|l|}{ Harvesting time } & Early-late June & Early-mid. June \\
\hline \multicolumn{2}{|l|}{ Planting density, individual $/ \mathrm{m}^{2}$} & 34.4 & 37.9 \\
\hline \multicolumn{2}{|l|}{ Cultivation area (ha) } & 0.29 & 0.65 \\
\hline \multicolumn{2}{|l|}{ Compost rate $\left(\mathrm{t} \cdot \mathrm{ha}^{-1}\right)$} & $35 \pm 14^{z}$ & $53 \pm 18$ \\
\hline \multirow[t]{4}{*}{ Quantity in compost $\left(\mathrm{kg} \cdot \mathrm{ha}^{-1}\right)$} & $\mathrm{N}^{\mathrm{y}}$ & $244 \pm 75$ & $399 \pm 124$ \\
\hline & $\mathrm{P}$ & $103 \pm 22$ & $247 \pm 106$ \\
\hline & $\mathrm{K}$ & $182 \pm 59$ & $309 \pm 95$ \\
\hline & OM & $13,883 \pm 5,637$ & $21,075 \pm 7,387$ \\
\hline \multirow[t]{4}{*}{ Quantity in basal fertilizer ${ }^{\mathrm{x}}\left(\mathrm{kg} \cdot \mathrm{ha}^{-1}\right)$} & $\mathrm{N}$ & $164 \pm 143$ & $170 \pm 54$ \\
\hline & $\mathrm{P}$ & $48 \pm 31$ & $44 \pm 17$ \\
\hline & $\mathrm{K}$ & $44 \pm 28$ & $78 \pm 34$ \\
\hline & $\mathrm{OM}$ & $3,089 \pm 2,376$ & $66 \pm 186$ \\
\hline \multirow[t]{4}{*}{ Quantity in top dress $\left(\mathrm{kg} \cdot \mathrm{ha}^{-1}\right)$} & $\mathrm{N}$ & $47 \pm 27$ & $178 \pm 55$ \\
\hline & $\mathrm{P}$ & $15 \pm 19$ & 0.0 \\
\hline & $\mathrm{K}$ & $14 \pm 18$ & $62 \pm 47$ \\
\hline & $\mathrm{OM}$ & $949 \pm 786$ & 0.0 \\
\hline \multirow{4}{*}{$\begin{array}{l}\text { Total quantity in applied compost } \\
\text { and fertilizer }\left(\mathrm{kg} \cdot \mathrm{ha}^{-1}\right)\end{array}$} & $\mathrm{N}$ & $456 \pm 176$ & $747 \pm 142$ \\
\hline & $\mathrm{P}$ & $166 \pm 33$ & $291 \pm 103$ \\
\hline & $\mathrm{K}$ & $241 \pm 71$ & $449 \pm 117$ \\
\hline & OM & $17,921 \pm 7,373$ & $21,141 \pm 7,429$ \\
\hline \multicolumn{2}{|l|}{$\begin{array}{l}\text { Irrigation frequency during the } \\
\text { growing season }\end{array}$} & 2.4 & 2.3 \\
\hline \multicolumn{2}{|l|}{ Lime, percent of surveyed farmers } & 62.5 & 50.0 \\
\hline \multirow[t]{3}{*}{ Frequency of pesticide spray } & Fungicide & 1.0 & 5.4 \\
\hline & Insecticide & 0.0 & 6.0 \\
\hline & Herbicide & 0.0 & 1.0 \\
\hline Biostimulants, percent of & & 25 & 88 \\
\hline
\end{tabular}

${ }^{\mathrm{z}_{\mathrm{SD}}}$.

Black PE

Transparent PE

${ }^{\mathrm{y}} \mathrm{N}=$ nitrogen; $\mathrm{P}=$ phosphorus; $\mathrm{K}=$ potassium; $\mathrm{OM}=$ organic matter; $\mathrm{PE}=$ polyethylene.

${ }^{\mathrm{x}}$ Fertilizers were applied as organic fertilizer in organic onion and as organic or inorganic fertilizer in the conventional one. 
manure compost, whereas organic farmers are not allowed to use those without regulated processes according to the Korean organic certification system. Organic farmers depend on organic fertilizers for nutrients, whereas conventional farmers depend on chemical fertilizers. The $\mathrm{N}$ and $\mathrm{P}$ quantities in the preplant application were not different; however, $\mathrm{N}$ and $\mathrm{K}$ amounts in top dressing were four times higher in conventional fields than in organic fields. The amount of nutrients applied to onion fields was approximately two times higher with conventional methods than with organic production. Furthermore, organic farmers applied natural pesticides such as Bordeaux mixture or sulfur and loess-containing compounds one time in March or April. In contrast, conventional growers sprayed fungicides and insecticides that averaged 5.4 and 6.0 times, respectively, during the onion-growing seasons. Pest problems such as downy mildew [Peronospora destructor (Berk.) Caspary], Stemphylium leaf blight [Stemphylium vesicarium (Wallr.) Simm], or onion maggots (Delia antique Meigen) were not detected in both systems because organic onions were not cropped continuously and received certified organic pesticides, whereas conventional fields received chemical pesticides. Black polyethylene film was used as a mulch in organic onions for weed control, yet transparent film was common in conventional onions because it increases the soil temperature during the winter season and promotes initial plant growth in early spring (Suh and Kim, 1991).
Soil physical and chemical properties. Significant differences between organic and conventional soils were not found in the physical and chemical properties of the preplant soil (Table 2). In early April, organic soils had a significantly higher exchangeable $\mathrm{Mg}$ content than conventional soils. Significant differences between organic and conventional soils in early May were found with $\mathrm{pH}$ and $\mathrm{NO}_{3}-\mathrm{N}$ content. At harvest, there were no significant differences between both soils. Organic soil $\mathrm{pH}$ did not change from preplant to early May, whereas conventional soil $\mathrm{pH}$ decreased from 6.4 before transplanting to 5.8 at harvest. Soil acidification resulted from chemical fertilizers such as urea $\mathrm{N}$ and ammonium nitrate fertilizer (Barak et al., 1997). Nitrate-N content in the conventional soil increased throughout the growing season as a result of the availability of applied chemical $\mathrm{N}$ fertilizers. There were no differences in $\mathrm{BD}, \mathrm{OM}$, or $\mathrm{N}$ contents between organic and conventional soils because both soils received abundant amounts of organic materials from the compost and organic fertilizer (Table 1). Conventional onion growers believe that composted animal manure application is as important as chemical fertilizers for improving soil fertility and onion bulb productivity.

Plant growth and bulb yield. Onion plant growth was significantly greater in the conventional field than in the organic field (Table 3). In early April, corresponding with the initial vegetative growth, the number of leaves, plant height, and bulb diameter of the conventional onions were 1.5 times greater than those of their counterparts. Furthermore, conventional onions had three times more fresh foliage weight compared with organic onions and two times greater bulb fresh weight compared with organic onions. However, dry matter content of the tops was significantly greater in the organic onions compared with the conventional onions. Bulb dry matter content was greater in the organic onions, but not statistically significant $(P=0.062)$ in early April. In early May, corresponding with initial bulb development, organic onions grew twice as many leaves and doubled in plant height, grew 3.5 times in bulb diameter, 12 times in top fresh weight, and 15 times in bulb fresh weight compared with onions 1 month earlier, but they did not catch up with their conventional counterparts. The top and bulb dry matter contents for the organic onions were, however, significantly greater with the organic onions in early May. At harvest, bulb fresh weight of organic onions was $175.6 \mathrm{~g} / \mathrm{plant}$, which was $44.6 \mathrm{~g}$ lower than that of the conventional onions. Finally, at harvest there were differences in top or bulb dry matter content between conventional and organic onions.

The differences in growth parameters affected onion bulb yields (Table 4). Organic onion bulb yield was $55.9 \mathrm{t} \cdot \mathrm{ha}^{-1}$, which was $15.6 \mathrm{t}$ lower than that of the conventional onions. Greater bulb yield of conventional onions was primarily the result of increases in the large-sized yield. Although conventional onions had a greater number of bolters and doubles compared with their counterparts, it

Table 2. Comparison of soil physical and chemical properties as affected by organic and conventional methods.

\begin{tabular}{|c|c|c|c|c|c|c|c|c|c|c|c|c|}
\hline \multirow{2}{*}{$\begin{array}{l}\text { Investigation } \\
\text { time }\end{array}$} & \multirow{2}{*}{$\begin{array}{l}\text { Production } \\
\text { methods }\end{array}$} & \multirow{2}{*}{$\begin{array}{c}\mathrm{BD}^{\mathrm{z}} \\
\left(\mathrm{kg} \cdot \mathrm{cm}^{-3}\right)\end{array}$} & \multirow{2}{*}{$\begin{array}{c}\text { WC } \\
\left(\mathrm{g} \cdot \mathrm{kg}^{-1}\right)\end{array}$} & \multirow[b]{2}{*}{$\mathrm{pH}$} & \multirow{2}{*}{$\begin{array}{c}\mathrm{EC} \\
\left(\mathrm{dS} \cdot \mathrm{m}^{-1}\right)\end{array}$} & \multirow{2}{*}{$\begin{array}{c}\mathrm{OM} \\
\left(\mathrm{g} \cdot \mathrm{kg}^{-1}\right)\end{array}$} & \multirow{2}{*}{$\begin{array}{c}\mathrm{N} \\
\left(\mathrm{mg} \cdot \mathrm{kg}^{-1}\right)\end{array}$} & \multirow{2}{*}{$\begin{array}{c}\mathrm{NO}_{3}-\mathrm{N} \\
\left(\mathrm{mg} \cdot \mathrm{kg}^{-1}\right)\end{array}$} & \multirow{2}{*}{$\begin{array}{c}\text { Av. P } \\
\left(\mathrm{mg} \cdot \mathrm{kg}^{-1}\right)\end{array}$} & \multicolumn{3}{|c|}{ Ex. cation $\left(\mathrm{cmol}_{\mathrm{c}} \cdot \mathrm{kg}^{-1}\right)$} \\
\hline & & & & & & & & & & $\mathrm{K}$ & $\mathrm{Ca}$ & $\mathrm{Mg}$ \\
\hline \multirow[t]{3}{*}{ Preplant } & Organic & 1.23 & 24.8 & 6.6 & 0.63 & 32.8 & 1.72 & 18.8 & 141.4 & 1.03 & 3.92 & 2.11 \\
\hline & Conventional & 1.19 & 26.0 & 6.4 & 0.44 & 33.7 & 1.81 & 7.1 & 183.0 & 1.17 & 3.22 & 1.71 \\
\hline & Probabilities & 0.540 & 0.820 & 0.409 & 0.270 & 0.893 & 0.822 & 0.261 & 0.429 & 0.643 & 0.560 & 0.075 \\
\hline \multirow[t]{3}{*}{ Early April } & Organic & 1.19 & 31.6 & 6.6 & 0.70 & 34.2 & 1.71 & 20.8 & 197.3 & 1.37 & 4.22 & 1.97 \\
\hline & Conventional & 1.11 & 36.6 & 6.1 & 0.67 & 32.6 & 1.80 & 32.4 & 263.9 & 1.25 & 3.75 & 1.54 \\
\hline & Probabilities & 0.284 & 0.400 & 0.117 & 0.776 & 0.801 & 0.805 & 0.210 & 0.168 & 0.664 & 0.676 & 0.027 \\
\hline \multirow[t]{3}{*}{ Early May } & Organic & 1.09 & 15.8 & 6.6 & 0.62 & 34.7 & 1.44 & 8.5 & 193.3 & 1.56 & 5.22 & 2.39 \\
\hline & Conventional & 1.12 & 17.3 & 5.9 & 0.80 & 32.3 & 1.62 & 37.0 & 268.1 & 1.34 & 4.19 & 1.86 \\
\hline & Probabilities & 0.580 & 0.566 & 0.045 & 0.235 & 0.726 & 0.603 & 0.037 & 0.153 & 0.506 & 0.550 & 0.089 \\
\hline \multirow[t]{3}{*}{ Harvest } & Organic & 1.13 & 22.2 & 6.2 & 0.83 & 35.0 & 1.62 & 20.2 & 213.2 & 1.29 & 4.55 & 2.26 \\
\hline & Conventional & 1.16 & 25.2 & 5.8 & 0.88 & 34.2 & 1.83 & 39.5 & 297.6 & 1.09 & 3.66 & 1.82 \\
\hline & Probabilities & 0.641 & 0.344 & 0.121 & 0.769 & 0.912 & 0.559 & 0.096 & 0.105 & 0.473 & 0.488 & 0.072 \\
\hline
\end{tabular}

${ }_{\mathrm{z}} \mathrm{BD}=$ bulk density; $\mathrm{WC}=$ water content $\mathrm{EC}=$ electrical conductivity; $\mathrm{OM}=$ organic matter; $\mathrm{N}=$ nitrate; $\mathrm{NO}$-N $=$ nitrate nitrogen; $\mathrm{S}=$ sulfur; Av. $\mathrm{P}=$ available phosphorus; Ex. cation = exchangeable cations; $\mathrm{K}=$ potassium; $\mathrm{Ca}=$ calcium; $\mathrm{Mg}=$ magnesium.

Table 3. Comparison of growth characteristics of onion plants as affected by organic and conventional methods

\begin{tabular}{|c|c|c|c|c|c|c|c|c|}
\hline \multirow[b]{2}{*}{ Investigation time } & \multirow{2}{*}{$\begin{array}{l}\text { Production } \\
\text { methods }\end{array}$} & \multirow[b]{2}{*}{ No. of leaves } & \multirow[b]{2}{*}{$\mathrm{Ht}(\mathrm{cm})$} & \multirow[b]{2}{*}{ Bulb diam (mm) } & \multicolumn{2}{|c|}{ Fresh wt (g/plant) } & \multicolumn{2}{|c|}{ Dry matter $\left(\mathrm{g} \cdot \mathrm{kg}^{-1}\right)$} \\
\hline & & & & & Top & Bulb & Top & Bulb \\
\hline \multirow{3}{*}{ Early April } & Organic & 4.3 & 28.9 & 10.0 & 6.0 & 2.7 & 109.7 & 111.1 \\
\hline & Conventional & 6.6 & 42.3 & 15.1 & 19.4 & 6.2 & 98.2 & 105.1 \\
\hline & Probabilities & $<0.001$ & $<0.001$ & $<0.001$ & $<0.001$ & $<0.001$ & $<0.001$ & 0.062 \\
\hline \multirow[t]{3}{*}{ Early May } & Organic & 7.6 & 73.9 & 35.3 & 76.4 & 41.0 & 88.8 & 107.7 \\
\hline & Conventional & 8.7 & 85.3 & 46.3 & 113.5 & 74.4 & 84.3 & 101.4 \\
\hline & Probabilities & 0.004 & 0.004 & 0.003 & 0.003 & 0.003 & 0.036 & 0.029 \\
\hline \multirow[t]{3}{*}{ Harvest } & Organic & - & - & 68.4 & 18.3 & 175.6 & 203.4 & 81.8 \\
\hline & Conventional & - & - & 75.2 & 19.1 & 220.2 & 175.0 & 80.5 \\
\hline & Probabilities & - & - & 0.037 & 0.927 & 0.054 & 0.582 & 0.632 \\
\hline
\end{tabular}


had no significant effect on the reduction in the marketable bulb yield.

The difference in plant growth and yield between conventional and organic agricultural practices began with the initial vegetative growth stage. By means of soil nutrients supply, the greater $\mathrm{NO}_{3}-\mathrm{N}$ concentration in the conventional soil probably played a role in the increased growth rate. Ells et al. (1993) concluded that when greater than $42 \mathrm{mg} \cdot \mathrm{kg}^{-1}$ of $\mathrm{NO}_{3}-\mathrm{N}$ was initially present in the top 33 $\mathrm{cm}$ of soil and up to $1120 \mathrm{~mm}$ of irrigation water was applied, bulb yields greater than 50 Mt.ha ${ }^{-1}$ could be obtained without $\mathrm{N}$ fertilizer. During the growing season, the conventional soil $\mathrm{NO}_{3}-\mathrm{N}$ concentration ranged from 32.4 to $39.5 \mathrm{mg} \cdot \mathrm{kg}^{-1}$, whereas the organic soil $\mathrm{NO}_{3}-\mathrm{N}$ concentration was between 8.5 and $20.8 \mathrm{mg} \cdot \mathrm{kg}^{-1}$. The amounts of $\mathrm{N}, \mathrm{P}$, and $\mathrm{K}$ recommended in Korea are $240 \mathrm{~kg} \cdot \mathrm{ha}^{-1}, 33.6$ $\mathrm{kg} \cdot \mathrm{ha}^{-1}$, and $128 \mathrm{~kg} \cdot \mathrm{ha}^{-1}$, respectively [Rural Development Administration (RDA), 2006]. In addition, cattle manure compost is recommended at $20 \mathrm{t} \cdot \mathrm{ha}^{-1}$. The quantity of N, P, and $\mathrm{K}$ applied from chemical and organic fertilizer in the conventional soil was $348 \mathrm{~kg} \cdot \mathrm{ha}^{-1}$, $44 \mathrm{~kg} \cdot \mathrm{ha}^{-1}$, and $140 \mathrm{~kg} \cdot \mathrm{ha}^{-1}$ of $\mathrm{N}, \mathrm{P}$, and $\mathrm{K}$, respectively, whereas the organic soil provided at $211 \mathrm{~kg} \cdot \mathrm{ha}^{-1}, 63 \mathrm{~kg} \cdot \mathrm{ha}^{-1}$, and 59 $\mathrm{kg} \cdot \mathrm{ha}^{-1}$ of $\mathrm{N}, \mathrm{P}$, and $\mathrm{K}$, respectively (Table 1). Although the organic soil received a lower quantity of these nutrients compared with the conventional soil, the nutrient content in soil was not significantly different (Table 1). This might be the result of a slow release of organic fertilizer in organic soil and lower nutrient removal by organic onions. The optimum ranges of soil chemical nutrients for bulb onions are a pH of 6.0 to $6.5,25$ to 35 $\mathrm{g} \cdot \mathrm{kg}^{-1}$ of OM, 129 to $168 \mathrm{mg} \cdot \mathrm{kg}^{-1}$ of available $\mathrm{P}$, and 0.39 to $0.70 \mathrm{cmol}_{\mathrm{c}} \cdot \mathrm{kg}^{-1}, 5.8$ to 6.7 $\mathrm{cmol}_{\mathrm{c}} \cdot \mathrm{kg}^{-1}$, and 2.1 to $2.7 \mathrm{cmol}_{\mathrm{c}} \cdot \mathrm{kg}^{-1}$ in exchangeable $\mathrm{K}, \mathrm{Ca}$, and $\mathrm{Mg}$, respectively (RDA, 2006). Exchangeable $\mathrm{Ca}$ and $\mathrm{Mg}$ content was slightly lower in both organic and conventional soil compared with the optimum ranges, whereas available $\mathrm{P}$ and exchangeable $\mathrm{K}$ content were higher than the ranges. Therefore, except for the $\mathrm{NO}_{3}-\mathrm{N}$ content during the growing season, no nutrients should affect the yield difference between the two systems. Then, what caused this significant difference? For overwintering onions, the soil temperature during winter and early spring significantly affects both the growth and yield (Siwek et al., 2013). The transparent plastic film enhanced onion growth and yield over the black plastic film (Wang et al., 2009), which is the result of higher soil temperatures with the transparent film compared with the black film during the winter and spring seasons (Hwang et al., 1996; Suh and Kim, 1991). Organic onions were grown with black plastic film largely as a result of weed control, which caused the organic onions to grow more slowly and ultimately resulted in lower bulb productivity than the conventional onions. To increase the yield of organic onions, several agricultural practices might need to be corrected, including earlier sowing and transplanting, later harvest, using extra protection materials to increase soil temperatures during winter, etc.

Plant nutrients and uptakes. Foliar $\mathrm{P}$ and $\mathrm{K}$ content were significantly greater in conventional onions than in organic onions in early April (Table 5). In early May, bulb N and $\mathrm{P}$ content of conventional onions was significantly greater than that of organic onions. Foliar nutrient uptake was not significantly different between organic and conventional onions at harvest, although conventional onions had a significantly greater foliar uptake during other growth stages and additionally in bulbs at all stages (Table 6). This difference could be explained by the foliar fresh weight at harvest (Table 3). When conventional onions completed bulb maturity in mid-June, organic onions still had many green leaves and were still immature. Delayed harvest for organic onions could be risky as a result of the higher temperatures and the onset of the monsoon season. Nevertheless, a 1-week later harvest should be one of the strategies for greater productivity and quality in organic onion.

Table 4. Comparison of bulb yield characteristics of onion plant as affected by organic and conventional methods.

\begin{tabular}{|c|c|c|c|c|c|c|c|c|c|c|}
\hline \multirow{2}{*}{$\begin{array}{l}\text { Production } \\
\text { methods }\end{array}$} & \multicolumn{4}{|c|}{ Marketable yield (t.ha-1) } & \multicolumn{5}{|c|}{ Unmarketable yield $\left(\mathrm{t} \cdot \mathrm{ha}^{-1}\right)$} & \multirow{2}{*}{$\begin{array}{c}\text { Stand reduction } \\
(\%)\end{array}$} \\
\hline & Large $^{z}$ & Medium & Small & Total & Bolters & Doubles & Rot & Cull & Total & \\
\hline Conventional & $30.0 \pm 24.8$ & $39.4 \pm 14.3$ & $2.1 \pm 1.4$ & $71.5 \pm 13.0$ & 1.51 & 3.26 & 0.71 & 0.06 & 5.54 & 4.8 \\
\hline
\end{tabular}

${ }^{\mathrm{z}}$ Size categories in bulb diameter: large $(8.0 \mathrm{~cm}$ or greater), medium $(6.0$ or greater and less than $8.0 \mathrm{~cm})$, small $(4.0$ or greater and less than $6.0 \mathrm{~cm})$, and cull (less than $4.0 \mathrm{~cm})$.

Table 5. Comparison of nutrient contents of onion plant as affected by organic and conventional methods on a fresh weight basis.

\begin{tabular}{|c|c|c|c|c|c|c|c|c|c|c|c|c|c|}
\hline \multirow[b]{2}{*}{ Investigation time } & \multirow[b]{2}{*}{ Production methods } & \multicolumn{6}{|c|}{ Top $\left(\mathrm{g} \cdot \mathrm{kg}^{-1}\right)$} & \multicolumn{6}{|c|}{ Bulb $\left(\mathrm{g} \cdot \mathrm{kg}^{-1}\right)$} \\
\hline & & $\mathrm{C}^{\mathrm{z}}$ & $\mathrm{N}$ & $\mathrm{P}$ & $\mathrm{K}$ & $\mathrm{Ca}$ & $\mathrm{Mg}$ & $\mathrm{C}$ & $\mathrm{N}$ & $\mathrm{P}$ & $\mathrm{K}$ & $\mathrm{Ca}$ & $\mathrm{Mg}$ \\
\hline \multirow{2}{*}{ Early April } & Organic & 43.0 & 4.02 & 0.22 & 3.70 & 0.64 & 0.21 & 40.4 & 3.35 & 0.24 & 3.62 & 0.43 & 0.21 \\
\hline & Conventional & 41.6 & 4.01 & 0.31 & 4.14 & 0.60 & 0.18 & 38.7 & 3.22 & 0.32 & 3.75 & 0.58 & 0.30 \\
\hline \multirow{3}{*}{ Early May } & Organic & 35.9 & 1.95 & 0.15 & 2.86 & 0.59 & 0.23 & 42.1 & 0.94 & 0.22 & 1.59 & 0.30 & 0.13 \\
\hline & Conventional & 34.3 & 2.10 & 0.16 & 2.72 & 0.62 & 0.20 & 42.4 & 1.34 & 0.29 & 1.68 & 0.34 & 0.13 \\
\hline & Probabilities & 0.093 & 0.221 & 0.335 & 0.230 & 0.465 & 0.168 & 0.823 & 0.001 & $<0.001$ & 0.474 & 0.561 & 0.911 \\
\hline Harvest & Organic & 72.9 & 3.68 & 0.10 & 6.16 & 5.64 & 0.96 & 33.2 & 1.36 & 0.19 & 1.26 & 0.22 & 0.10 \\
\hline
\end{tabular}

${ }^{\mathrm{z}} \mathrm{C}=$ carbon; $\mathrm{N}=$ nitrogen; $\mathrm{P}=$ phosphorus; $\mathrm{K}=$ potassium; $\mathrm{Ca}=$ calcium; $\mathrm{Mg}=$ magnesium.

Table 6. Comparison of nutrient uptake of onion plants as affected by organic and conventional methods.

\begin{tabular}{|c|c|c|c|c|c|c|c|c|c|c|c|c|c|}
\hline \multirow[b]{2}{*}{ Investigation time } & \multirow[b]{2}{*}{ Production methods } & \multicolumn{6}{|c|}{ Top $\left(\mathrm{kg} \cdot \mathrm{ha}^{-1}\right)$} & \multicolumn{6}{|c|}{ Bulb (kg.ha $\left.{ }^{-1}\right)$} \\
\hline & & $\mathrm{C}^{\mathrm{z}}$ & $\mathrm{N}$ & $\mathrm{P}$ & $\mathrm{K}$ & $\mathrm{Ca}$ & $\mathrm{Mg}$ & $\mathrm{C}$ & $\mathrm{N}$ & $\mathrm{P}$ & $\mathrm{K}$ & $\mathrm{Ca}$ & $\mathrm{Mg}$ \\
\hline \multirow[t]{3}{*}{ Early April } & Organic & 81.9 & 7.7 & 0.48 & 7.4 & 1.26 & 0.38 & 34.3 & 2.89 & 0.24 & 3.21 & 0.43 & 0.29 \\
\hline & Conventional & 293.0 & 28.0 & 2.21 & 29.3 & 4.37 & 1.25 & 86.9 & 7.05 & 0.69 & 8.37 & 1.26 & 0.65 \\
\hline & Probabilities & $<0.001$ & $<0.001$ & $<0.001$ & $<0.001$ & 0.002 & $<0.001$ & $<0.001$ & $<0.001$ & $<0.001$ & $<0.001$ & 0.003 & $<0.001$ \\
\hline \multirow[t]{3}{*}{ Early May } & Organic & 880 & 48.2 & 3.66 & 71.0 & 14.7 & 5.46 & 556 & 12.8 & 2.94 & 20.6 & 3.53 & 1.69 \\
\hline & Conventional & 1,384 & 84.3 & 6.63 & 110.7 & 24.9 & 7.89 & 1,035 & 33.2 & 7.24 & 41.8 & 7.50 & 3.17 \\
\hline & Probabilities & $<0.001$ & $<0.001$ & $<0.001$ & 0.002 & $<0.001$ & 0.015 & $<0.001$ & $<0.001$ & $<0.001$ & 0.002 & 0.004 & 0.005 \\
\hline \multirow[t]{3}{*}{ Harvest } & Organic & 311 & 16.5 & 0.44 & 28.2 & 27.1 & 4.90 & 1,893 & 77.5 & 10.7 & 72.4 & 12.5 & 5.6 \\
\hline & Conventional & 321 & 16.1 & 0.46 & 28.2 & 24.3 & 3.34 & 2,525 & 115.9 & 15.1 & 103.8 & 18.4 & 7.8 \\
\hline & Probabilities & 0.905 & 0.921 & 0.910 & 0.994 & 0.720 & 0.278 & 0.018 & 0.011 & 0.045 & 0.011 & 0.019 & 0.006 \\
\hline
\end{tabular}

${ }^{\mathrm{z}} \mathrm{C}=$ carbon; $\mathrm{N}=$ nitrogen; $\mathrm{P}=$ phosphorus; $\mathrm{K}=$ potassium; $\mathrm{Ca}=$ calcium; $\mathrm{Mg}=$ magnesium. 
Greater foliar $\mathrm{P}$ content of conventional onions in early April and in bulb $\mathrm{N}$ and $\mathrm{P}$ content in early May might result from greater soil $\mathrm{N}$ and $\mathrm{P}$ concentrations (Table 2 ); however, the uptake of these primary nutrients by onions with these two systems was substantially lower compared with the total quantity applied from compost and fertilizers (Table 1). Nitrogen, $\mathrm{P}$, and $\mathrm{K}$ uptakes were 94.0, 11.1, and $100.6 \mathrm{~kg} \cdot \mathrm{ha}^{-1}$, respectively, in organic onions, and 132.0, 15.6 , and $132.0 \mathrm{~kg} \cdot \mathrm{ha}^{-1}$, respectively, in their conventional counterparts (Table 6). Organic onions absorbed only $20.6 \%$ of N, $6.7 \%$ of $\mathrm{P}$, and $41.7 \%$ of $\mathrm{K}$ from inputs, whereas conventional onions did the same with $17.7 \%$ of N, $5.4 \%$ of $\mathrm{P}$, and $29.4 \%$ of $\mathrm{K}$. Frequently, excessive nutrient content in the soil and high application rates caused no effect or had a negative effect on bulb yield (Lee et al., 2012; Shock, 2005; Westerveld et al., 2003).

In conclusion, slower growth in early spring and low $\mathrm{NO}_{3}-\mathrm{N}$ release in organic soils would be the main problems decreasing yield in organic onions as compared with conventional onions. To accelerate an initial vegetative growth of organic onion plants, planting large seedlings or transplanting 1 week earlier as compared with conventional planting or using covering materials such as nonwoven fabric could be effective at improving yield. Also, because organic onions were grown with black plastic film, its vegetative growth and bulb development occurred later than the conventional onions. Therefore, a 1-week later harvest could improve both the bulb yield and maturity. Furthermore, because the organic fertilizer did not release inorganic $\mathrm{N}$ as well as chemical fertilizers, applying the fertilizer before transplanting as well as applying a liquid organic fertilizer in the vegetative growth stage could be effective for organic onion production.

\section{Literature Cited}

Abdelrazzag, A. 2002. Effect of chicken manure, sheep manure and inorganic fertilizer on yield and nutrients uptake by onion. Pak. J. Biol. Sci. 5:266-268.

Barak, P., B.O. Jobe, A.R. Krueger, L.A. Peterson, and D.A. Laird. 1997. Effects of long-term soil acidification due to nitrogen fertilizer inputs in Wisconsin. Plant Soil 197:61-69.

Boyhan, G.E., R.J. Hicks, R.L. Torrance, C.M. Riner, and R. Hill. 2010. Evaluation of poultry litter and organic fertilizer rate and source for production of organic short-day onions. HortTechnology 20:304-307.

Ells, J.E., A.E. McSay, P.N. Soltanpour, F.C. Schweissing, M.F. Bartolo, and E.C. Kruse. 1993. Onion irrigation and nitrogen leaching in the Arkansas valley of Colorado, 1990-1991. HortTechnology 3:185-187.

Fink, M., C. Feller, H.C. Scharpf, U. Weier, A. Maync, J. Ziegler, P.J. Paschold, and K. Strohmeyer. 1999. Nitrogen, phosphorus, potassium and magnesium contents of field vegetablesRecent data for fertilizer recommendations and nutrient balances. J. Plant Nutr. Soil Sci. 162:71-73.

Gericke, S. and B. Kurmies. 1952. The colorimetric phosphorus analysis with ammonium-vandatemolybdate and its application in plant analysis. Plant Fert. Soil 59:235-247.

Hwang, H.J., J.K. Suh, I.J. Ha, and Y.W. Ryu. 1996. Effects of planting time and mulching material on growth and seed yield for seed production culture in onion. Rural Development Administration J. Agr. Sci. 38:640-647 [in Korean].

Lee, J. 2010. Effect of application methods of organic fertilizer on growth, soil chemical properties and microbial densities in organic bulb onion production. Sci. Hort. 124:299-305.

Lee, J. 2012. Evaluation of composted cattle manure rate on bulb onion grown with reduced rates of chemical fertilizer. HortTechnology 22:798-803.

Lee, J., J. Song, and S. Lee. 2012. Excessive fertilization is detrimental to yield and quality for onion grown on high organic matter content paddy soils. Intl. J. Veg. Sci. 18:235-244.

Mogren, L.M., S. Caspersen, M.E. Olsson, and U.E. Gertsson. 2009. Organically fertilized onions (Allium cepa L.): Effects of the fertilizer placement method on quercetin content and soil nitrogen dynamics. J. Agr. Food Chem. 56:361-367.

Mousa, M.A.A. and M.F. Mohamed. 2009. Enhanced yield and quality of onion (Allium cepa L. cv Giza 6) produced using organic fertilization. Assiut Univ. Bull. Environ. Res. 12:9-18.

McIntosh, J.L. 1969. Bray and Morgan soil extractants modified for testing acid soils from different parent materials. Agron. J. 61:259265.

National Agricultural Products Quality Management Service. 2013. Environment friendly agricultural products information. 1 Aug. 2013. <http:// www.naqs.go.kr/index.jsp $>$ [in Korean].

Rural Development Administration. 2006. The standard of fertilizer application on crop species. National Institute of Agricultural Science and Technology, Rural Development Administration, Suwon, Korea [in Korean].
Saviello, G., P. Iovieno, R. Morelli, D. Baldantoni, L. Morra, and A. Alfani. 2013. Long-term compost amendment of a Mediterranean horticultural soil. Part I: Relationships among biological and chemical soil quality and the yield of two crops. In: 15th International Conference RAMIRAN 2013. p. 1-4.

Sellen, D., J.H. Tolman, D. Glenn, R. McLeod, A. Weersink, and E.K. Yiridoe. 1995. A comparison of finanacial returns during early transition from conventional to organic vegetable production. Vegetable Crop Production 1:11-39.

Shock, C.C. 2005. Nitrogen management with drip and sprinkler irrigation. In: Western Nutrient Management Conference. 6:66-71.

Siwek, P., A. Libik, and I. Zawiska. 2013. The impact of biogradable nowoven fabric covers on the yield and quality of overwintering onions. Acta Sci. Pol., Hortorun Cultus 12:311.

Slavin, W. 1968. Atomic absorption spectroscopy. Chem. Anal. 25:87-90.

Statistics Korea (KOSTST). 2013. Production of barley, garlic and onions in 2013. Press Releases No. 1333. <http://kostat.go.kr/portal/ english/news/1/1/index.board $>$.

Suh, J.K. and Y.B. Kim. 1991. Study on improvement of mulching culture method in onion (Allium cepa L.). Res. Rept. of Rural Development Administration 33:31-36 [in Korean].

Sullivan, D.M., B.D. Brown, C.C. Shork, D.A Horneck, R.G. Stevens, G.Q. Pelter, and E.B.G. Feibert. 2001. Nutrient management for onions in the Pacific Northwest. Pacific Northwest Extension Publications. p. 2-7.

Varina, C.S. and F.M. Roka. 2000. Comparison of plastic mulch and bare-ground production and economics for short-day onions in a semitropical environment. HortTechnology 10:326-330.

Vidigal, S.M., M.A.N. Sediyama, M.W. Pedrosa, and M.R. Santos. 2010. Onion yield in organic system using compost of swine manure. Horticultura Brasileira 28:168-173.

Wang, Y.G., X. Kun, Z. Kai, and X. Ning. 2009. Effects of coloured plastic film on the growth and yield of onion. China Vegetables 6:4651.

Westerveld, S., A.W. McKeown, C.D. ScottDupree, and M.R. McDonald. 2003. How well do critical nitrogen concentrations work for cabbage, carrot, and onion crops? HortScience 38:1122-1128.

Yoldas, F., S. Ceylan, N. Mordogan, and B.C. Esetlili. 2011. Effect of organic and inorganic fertilizers on yield and mineral content of onion (Allium cepa L.). Afr. J. Biotechnol. 10:1148811492.

Zink, F.W. 1966. Studies on the growth rate and nutrient absorption of onion. Hillgardia $37: 203-212$. 